\title{
The Influence of Knowledge Economy Development on Competitiveness of Southeastern Europe Countries ${ }^{3}$
}

\author{
Article history \\ Received: 10 June 2013 \\ Sent for revision: 21 June 2013 \\ Received in revised form: 08 July 2013 \\ Accepted: 09 July 2013 \\ Available online: 11 July 2013
}

\begin{abstract}
The purpose of this research is to analyze the influence of knowledge as a vital development resource on competitiveness of Southeastern Europe (SEE) countries. The aim is to identify correlation among the achieved knowledge economy development level, measured by the KEI (Knowledge Economy Index) and competitiveness level measured by the GCI (Global Competitiveness Index) in the SEE countries. The study is realized by using descriptive statistics, correlation, regression and comparative analysis. Structurally, the paper is composed of the following parts: analysis of the competitiveness of SEE countries according to the $\mathrm{GCl}$ and the KEl, as well as according to the pillars within the KEl, examination of interdependence $\mathrm{GCl}$ and $\mathrm{KEl}$ and examination of the impact of the pillar within the $\mathrm{KEI}$ on $\mathrm{GCl}$ in SEE countries. Research results indicate that there is a weak positive correlation between the $\mathrm{GCl}$ and $\mathrm{KEI}$. The results of this study provide recommendations to development policy makers in SEE countries.
\end{abstract}

Key words: Knowledge, Economy, Competition, SEE countries

\section{Uticaj unapređenja ekonomije znanja na konkurentnost zemalja Jugoistočne Evrope}

Apstrakt: Svrha ovog rada je da istraži uticaj znanja kao vitalnog razvojnog resursa na konkurentnost zemalja jugoistočne Evrope. Cilj rada je da se odgovarajućom metodologijom identifikuje povezanost dostignutog stepena razvoja ekonomije znanja

\footnotetext{
${ }^{1}$ University of Nis, Faculty of Economics, sokobk@gmail.com

${ }^{2}$ University of Nis, Faculty of Mathematics and Science, tanja.stanisic@gmail.com

${ }^{3}$ The paper was supported by the Ministry of Education, Science and Technological

Development, Republic of Serbia (Project 179066)
} 
Krstić B. et al.: The Influence of Knowledge Economy Development on...

merenog pomoću KEl (Knowledge Economy Index) u zemljama jugoistočne Evrope sa nivoom njihove konkurentnosti merene pomoću GCI (Global Competitiveness Index). Istraživanje se realizuje primenom metoda deskriptivne statistike, korelacione, regresione i komparativne analize. Rad je strukturiran iz sledećih segmenata: analiza konkurentnosti zemalja jugoistočne Evrope na osnovu GCl i KEl, kao i pilara u okviru $\mathrm{KEl}$, ispitivanje međuzavisnosti $\mathrm{GCl} i \mathrm{KEl} i$ ispitivanje uticaja pilara u okviru KEl na GCl u zemljama jugoistočne Evrope. Rezultati istraživanja ukazuju na postojanje slabe pozitivne korelacije između GCl i KEl. Takođe, dobijeni rezultati upućuju na preporuke kreatorima politika razvoja u zemljama jugoistočne Evrope.

Ključne reči: znanje, ekonomija, konkurencija, zemlje jugoistočne Evrope.

\section{Introduction}

Knowledge is the key factor of productivity of an enterprise and economic development of any country in terms of the dynamic competitive struggle in the global market. A request to improve the competitive position imposes a need to SEE countries to develop their knowledge resources, so that they can contribute to the improvement of their position in the world rankings as much as possible. The development of SEE countries in the future and the progress on the level of achieved competitiveness should be based on all factors and resources that lead to the construction of the economy, marked as knowledge economy. These economies should necessarily base their own production, distribution and export of products and services in the global market on knowledge and information, as well as on the growing of hightechnology investments. This must include the help of highly skilled and welleducated labor force, which will create, share, transfer, and use knowledge as a development resource more effectively. For that purpose, it is important to examine the achieved level of knowledge economy development in SEE countries and identify what is the influence of this development on the level of achieved competitiveness.

The purpose of this analysis is to examine the interdependence between $\mathrm{GCl}$ (Global Competitiveness Index) and KEI (Knowledge Economy Index), as well as, between $\mathrm{GCl}$ and pillars within KEI (Economic Incentive \& Institutional Regime, Innovation, Education, and ICT). The aim of this research is determining the influence of the pillars within $\mathrm{KEI}$ on value of $\mathrm{GCl}$ in SEE countries. In the purpose of realizing the given task, the paper is structured from the following parts. The first, we specify determinants of knowledge economy as a factor of competitiveness of enterprises and national economies. Research methodology and hypothesis are presented in the second part. The third part of the paper refers to the research results and discussions. In the purpose of testing research hypotheses, the third part of paper is structured in the following sections: a) Analysis of SEE countries' competitiveness according to $\mathrm{GCl}$ and KEl; b) Analysis of pillar within KEl in SEE countries; c) Examining the correlation between $\mathrm{GCl}$ and $\mathrm{KEI}$ in SEE countries; d) Analysis of influence of pillar within KEI on $\mathrm{GCl}$ in SEE countries. The results of this study provide recommendations to devel- 
opment policy makers in SEE countries and point out the necessity of improving the performance of all four pillars of the knowledge economy.

\section{Determinants of knowledge economy as a factor of competitiveness of enterprises and national economies}

Business is becoming increasingly complex in the process of globalization (Daniels, Radebaugh \& Sullivan, 2002). Employees' work must meet the requirements of increasing efficiency and enable getting the products and services of differentiated features compared to competitors. For that purpose, modern enterprises are challenged to develop and improve their skills and competence, but also to increase the level of expertise and level of innovation management and other employees. Highly competitive enterprises, in the so-called developed knowledge societies and economies, prepare its labor force better regarding the vital necessary competences. Work becomes more sophisticated. New, expanded, combined and multi-functional skills, which are acquired through a formal system education, training and practice during the working, are necessary in order to use the opportunities of the creation and appliance of personal implicit and structural (codified, organizational) knowledge to a greater extent.

An economy becomes knowledge economy by putting knowledge at the center of the process of economic development. The use of new, more efficient methods of production is increasing and productivity is rising along with increasing speed of the creation and dissemination of knowledge. The result is that the world economy becomes increasingly competitive. The share of the world trade, import and export in the world gross domestic product grew (Chen \& Dahlman, 2005), from 24\% in 1960 to $47 \%$ in 2002. Otherwise, the world gross domestic product is an indicator of globalization and competitiveness. The world economy, therefore, gets the character of the knowledge economy. Some of the national economies also have the attribute of the knowledge economy, because they use knowledge as a key "engine" of its economic growth. Therefore, an economy that effectively provides, creates, disseminates and exploits knowledge to accelerate its economic development is a knowledge-based economy. "A knowledge economy is the one in which knowledge in the form of intellectual capital is a primary factor of production" (Bedford, 2013, p. 278). Knowledge economy has a three attributes: learning, creativity and openness (Peters, 2010).

Globalization is the first economic trend of the economy based on knowledge (Andriessen, 2004). Inevitably, we are talking about a paradigm of knowledge after the end of the era of industrialization, because the point of view of the business under new conditions as well as understanding of the basis of the creation and improvement of competitiveness has changed. In today's economy, where uncertainty is the only absolute, the main source of competitive advantage is knowledge. When the market changes significantly, technology improves rapidly and number of competitors increases permanently, successful companies should create new knowledge constant- 
ly, spread it throughout the organization and quickly materialize it in the form of innovative products/services.

"Knowledge-based economies are the economies directly based on the production, distribution, and use of knowledge and information" (OECD, 1996, p. 7). New growth theory reflects the attempt to understand the role of knowledge and technology in driving productivity and economic growth. In this view, investments in research and development, education and training and new managerial work structures are key. Knowledge economy, which key component is intellectual capabilities, means production and services primarily based on knowledge-activities that contribute to an accelerated pace of technical and scientific advance (Powell, \& Snellman, 2004, p. 199). "Knowledge economy is what you get when firms bring together powerful computers and well-educated minds to create wealth" (Brinkley, 2006, p. 3). Knowledgebased economies are "economies in which the proportion of knowledge-intensive jobs is high, the economic weight of information sectors is a determining factor, and the share of intangible capital is greater than that of tangible capital in the overall stock of real capital" (Foray, 2004, p. ix).

All companies, and even the countries, compete in the knowledge economy in terms of the so-called new economy. In the past, the economies gained abundance and increased citizens' standard of living thanks to a combination of natural resources, labor and financial capital. Since knowledge took over primacy, "knowledge cold war" has been increasingly mentioned nowadays. The most developed countries are determined to create the conditions for the inflow and preventing outflow of knowledge. It is clear that the era of industrialization is replaced by the internet society or the era of the knowledge economy. The power "moved" from those who are investing money in the business to those who are using their knowledge and skills thus create value. Changes in the world economy of the last half-century reshaped the nature of the value creation dramatically. Under new conditions, existing products and services lose value, in the sense that customers buy less and look for new products that imply more knowledge. Therefore, it is emphasizing that the intangible component of the product - knowledge superannuates.

A special contribution of management in the $20^{\text {th }}$ century was multiple improvement of productivity of manual workers in production, while the most important contribution of management in this century will be the improvement of productivity of intellectual work, i.e. "knowledge workers" (Drucker, 1992). The most important property of a company in the $21^{\text {st }}$ century is professionals, creative and innovative employees, so the efficiency is largely determined by their productivity.

The Industrial Revolution dominated in the late $19^{\text {th }}$ and early $20^{\text {th }}$ century. The generating of profit was looked primarily through increasing of productivity in production process. Now, the wealth of the nation and the entire region depends on the level of knowledge and its effective and efficient implementation increasingly. Knowledge economy offers almost unlimited resources, because the man's ability to create knowledge, in fact, is unlimited. The knowledge organizations (Drucker, 1992) use 
their intellectual resources as the main source of competitive advantage. They, as a rule, have little tangible assets. Intangible assets of these organizations, mostly, exceed the value of their tangible assets even far. They compete based on its intellectual value, or by creating strikingly different and unique combinations that are necessary to meet significantly changeable consumer demands (Teece, 2000). These learning organizations are understood as a group of employees that continuously enhances its ability to create superior value compared to competitors. Their main feature is the ability to conform quickly, and innovate and restructure their businesses continuously. In the OECD study, the knowledge-based capital recognized as a new source of growth, which creates future benefits, but, unlike machines, equipment, vehicles and structures, they do not have a physical or financial embodiment. This non-tangible form of capital is key contributor to growth in advanced economies (OECD, 2012, p. 3).

Achieving of the competitive advantage in the era of the new economy means adopting new perspectives and concept of knowledge management based on value (Thissen, Andriesen, Deprez Lekanne, 1999). According to this concept, business success and competitiveness in the knowledge economy are based on the following principles: increasing the value of the company, increasing value for consumers, increasing value for the company and increasing value for the employees.

Comparative advantage exists when a company offers products/services to consumers that are different from the competition constantly, and this differentiation has some value for consumers. The company's ability to offer something different and more valuable to consumers constantly can be achieved only if the business activity of the company is, in some way, different from the competition. Competitive advantages have their source in the four skills (Wickham, 2001, p. 267): internal structure, the company's reputation, a way of company's innovating and company's strategic resource, or valuable property that is available to the company and to its competitors is not. These four abilities are relevant for each business activity. They can be related to three specific sources of competitive advantage, such as: cost, knowledge and relationships with the key stakeholders.

A company can achieve a competitive advantage by reducing costs in the era of knowledge economy. In other words, the company should be able to add value to their products/services more efficiently. "The knowledge economy opens new directions, and offers unprecedented opportunities to produce and sell on a mass scale, reduce costs, and customize to the needs of consumers, all at the same time" (Bratianu, \& Dinca, 2010, p. 210). Advantage in cost can be achieved through four key fields (Wickham, 2001, p. 267): lower costs of inputs, economies of scale, experience curve, and technological innovation. Knowledge can be very important for achieving a competitive advantage. The companies, therefore, can achieve an advantage if they have knowledge that competitors do not have. It can be (Wickham, 2001, p. 269): product knowledge, market knowledge, and technological knowledge. Competitive advantage in the era of knowledge economy can be achieved from relationships with 
Krstić B. et al.: The Influence of Knowledge Economy Development on...

key stakeholders. It may be difficult to copy knowledge and management skills derived from relationships with stakeholders. They retain in the company usually. Multiple confidence and unique resources can be identified as two possibilities for achieving a competitive advantage based on relationships with stakeholders. It comes from (Donaldson, \& O'Toole, 2002, p. 32): 1. mutual learning through established relationships with stakeholders; 2 . combining of complementary resources and capabilities that can sometimes lead to the creation of a new joint product, service or technology; 3. lower transaction costs than the competition, because networked stakeholders create an atmosphere of trust in which protective measures are not necessary usually.

Specific competitiveness of companies of one country is the basis of national competitiveness. This concept integrates microeconomic and macroeconomic factors of competitiveness. International competitiveness is shaped by numerous other factors also: exchange rates, interest rates, budget deficits, the quality of labor force, natural resources, management practices, a positive trade balance, increasing productivity, innovation, technology, scientific research, education system, comparative advantages and other.

\section{Research methodology and hypothesis}

Information base for this research consists of the information contained in The Global Competitiveness Report 2012-2013 and the data of the World Bank - Knowledge Economy Index (KEI) for 2012.

The methodology for measuring national and global competitiveness of the World Economic Forum (WEF) systematizes the key factors into 12 groups of factors in order to quantify the level of competitiveness of the national economy and rankings. These so-called competitiveness pillars are: basic factors (institutions, infrastructure, macroeconomic stability, health and primary education), the efficiency factors (higher education, goods market efficiency, labor markets efficiency, financial market development, technological competence/capacity, market size) and innovation factors (business/business process sophistication, innovation). Composite the Global Competitiveness Index $(\mathrm{GCl})$ is result of measuring many factors and variables.

In the modern era of knowledge economy, its determinants and variables have an influence on national competitiveness of countries. "Knowledge is recognized as the driver of productivity and economic growth and it leads to enhancing the significance of information, technologies and learning for economic performance" (Zitek, \& Klimova, 2011, p. 821). Measuring of the individual countries' progress in achieving the necessary conditions for building the knowledge economy is made possible by the application of the methodology of the World Bank Institute - Knowledge Assessment Methodology (KAM) and by Knowledge Economy Index designed based on KAM. 
The KAM methodology for evaluating the progress towards the knowledge society is the analysis of structural and qualitative indicators measured for each country, with the aim of quantifying the variables in the four pillars that are crucial for the development of the knowledge society and economy (The World Bank, 2004; Javalgi, Gross, Benoy \& Granot, 2011, p. 176):

1. Education (educated population, which is able to create, exchange and use knowledge);

2. Innovation system (effective innovation system, which includes enterprises, research centers, universities, consultants and other organizations that will be able to take advantage of the growing knowledge resources at the global level, to adapt them according to local needs and to produce new technologies);

3. Information and communication technologies (technologies that will enable the efficient creation, exchange and processing of information);

4. Institutional framework (economic and legal framework that will encourage efficient use of existing and new knowledge, and develop entrepreneurship).

KAM points out tracking the basic scorecard with 12 variables/criteria (three for each of the above-mentioned pillars of the knowledge economy).

The first pillar of the knowledge economy is Education. Improving the education system is of great importance for the economic development and competitiveness. The education system contributes to increasing of productivity and innovation based on development of competence of labor active population and rapid transfer of knowledge from educational and research institutions to various economic activities. In addition, the higher level of education has a positive impact on economic growth. The education system of a country is monitored by KAM methodology based on three variables/indicators: 1 . the literacy rate of the adult population; 2. gross percentage of the population in secondary education; 3. gross percentage of the population in higher education (The World Bank, 2004).

The second pillar of the knowledge economy is Innovation. The most developed regions, countries and the most competitive enterprises consider innovation as a critical factor of economic strength and development. The issue of monitoring the level of innovation activities in the national economy is complex because of the nature of innovation (DOC, 2008). Therefore, it is important to monitor a number of measures of innovation activities. These measures are relevant for the government of any country in order to use them for leading national economy to the development based on innovation. Innovation system is the "engine" of economic development in the modern economic environment. The analysis of this area aims to highlight the key shortcomings of the innovation system and to identify the priorities that economic policy makers should pay more attention to. KAM methodology solves measuring of innovation at the level of the national economy by incorporating three vital indicators: 1 . the number of researchers in the research and development sector per million populations; 2 . the number of professional and scientific articles per million populations; 3 . the number of patents per million populations. 
Krstić B. et al.: The Influence of Knowledge Economy Development on...

The third pillar of the knowledge economy is Information and communication technologies. The development of information and communication technologies in modern conditions is the most important factor of the intensity and dynamics of economic development. Development of this pillar of the knowledge economy is evaluated by the KAM methodology based on three criteria: 1. the number of telephone lines per 1000 population; 2 . the number of computers per 1000 population; 3 . the number of internet users per 10,000 population.

The fourth pillar of the knowledge economy is Institutional framework, which KAM methodology recognizes as a determinant of the knowledge economy index by taking into account: 1. tariff and non-tariff barriers, 2. regulatory quality, and 3. rule of law.

Figure 1 - KEI and KI Indexes

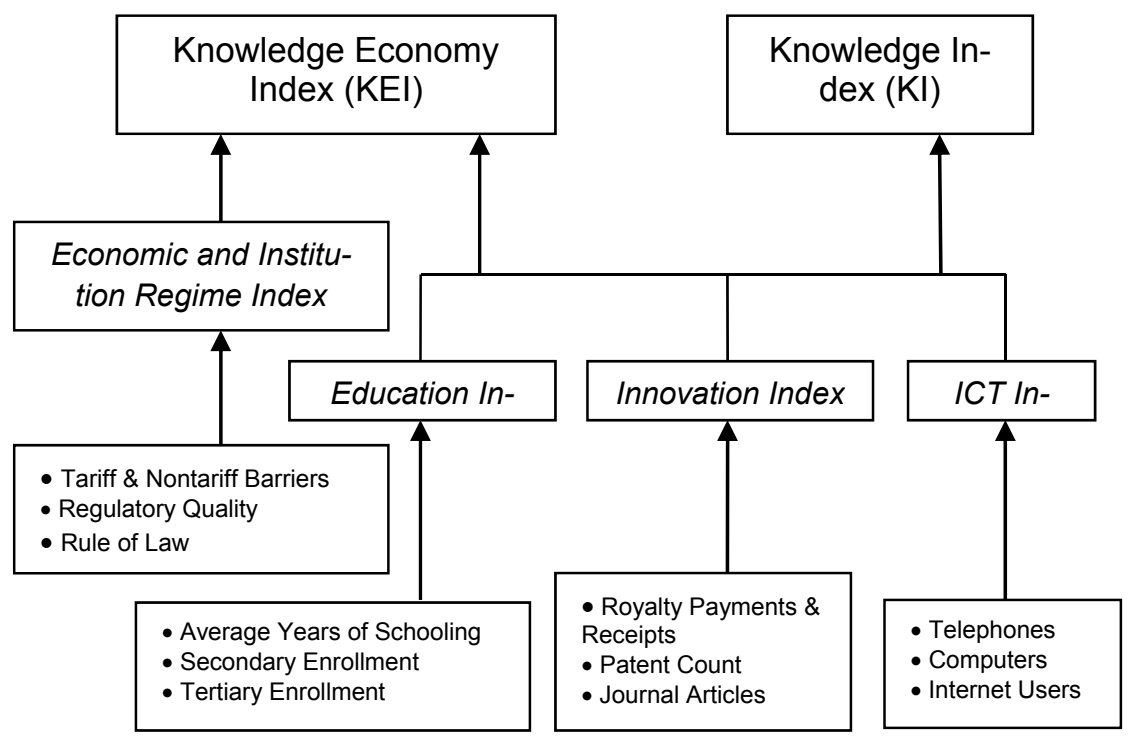

Source: The World Bank (WB), Knowledge Economy Index (KEl) 2012 Rankings,

http://siteresources.worldbank.org/INTUNIKAM/Resources/2012.pdf

The Knowledge Index $(\mathrm{KI})$ and the Knowledge Economy Index (KEI) are derivate by KAM. The Knowledge Economy Index, in contrast to the Knowledge Index, in addition to pillars Education, Innovation and ICT - Information and Communications Technologies, includes also pillar Economic Incentive and Institutional Regime (Fig. 1). While $\mathrm{KI}$ is an indication of the overall potential of knowledge development in all countries, KEI represents the overall level of development of a country or region towards the Knowledge Economy (Zitek, \& Klimova, 2011, p. 823). "The KEl assesses the relative effec-tiveness of each state's knowledge economy, the sector of the economy in which value lies increasingly in ideas, services, information, technological innovation and relationships" (Watkins \& Yandle, 2010, p. 107). Based on KEl, coun- 
tries can easily identify all the challenges and opportunities offered to them in the way of creating the knowledge economy and society. This method also assesses the readiness of countries in a competitive game in the modern business conditions, where knowledge and its applications in the field of innovation, entrepreneurship, research and development, are recognized as a key factor of the global economy growth and development. KEl indicates how a country environment conducive to the effective application of knowledge for the purpose of a comprehensive social and economic development.

$\mathrm{KEI}$ is an aggregate index that shows the overall level of achieved development of certain country or region towards a knowledge society. KEl index value ranges from 1 (worst) to 10 (best score). KEl is calculated as the average of normalized results in all four pillars of the knowledge society, where three key indicators represent each pillar. Normalization means the expression of different indicators using the same standards for measuring and reducing them to values between 0 (lowest score) to 10 (best score), on a scale which shows the values of all countries. Thus $10 \%$ of the best countries get normalized score between 9 and 10 , the next $10 \%$ of the countries between 8 and 9, etc.

The subject of this analysis is to examine the interdependence between $\mathrm{GCl}$ and $\mathrm{KEI}$, as well as, between $\mathrm{GCl}$ and pillars within $\mathrm{KEI}$ (Economic Incentive \& Institutional Regime, Innovation, Education, and ICT). The aim of this research is determining the influence of the pillars within $\mathrm{KEI}$ on value of $\mathrm{GCl}$ in SEE countries.

In accordance with the purpose of research, the authors tested the following hypotheses:

$\mathrm{H} 1$ : SEE countries are heterogeneous in terms of performances (scores of pillars within KEl) that determine the overall achieved level of the knowledge economy development.

$\mathrm{H} 2$ : There is correlation between competitiveness and the level of the knowledge economy development in SEE countries.

H3: The achieved level of the knowledge economy development in SEE countries does not have significant influence on their level of competitiveness.

The following methods are used in this research: descriptive statistics, comparative, correlation and regression analysis. Comparative analysis is used to determine the relative position of each country in the group of SEE countries (by value of $\mathrm{GCl}$, KEI and the pillar within $\mathrm{KEI}$ ), compared to the average value of these indices and pillar for group of SEE countries as a whole. Correlation analysis is used to examine the interdependence between $\mathrm{GCl}$ and $\mathrm{KEI}$ in SEE countries. The influence of pillars within $\mathrm{KEl}$ on value of $\mathrm{GCl}$ is measured by regression analysis. 
Krstić B. et al.: The Influence of Knowledge Economy Development on...

\section{Research results and discussions}

In the purpose of realizing the given task and testing hypotheses, the paper is structured in the following sections:

- Analysis of SEE countries' competitiveness according to $\mathrm{GCl}$ and $\mathrm{KEl}$;

- Analysis of pillar within KEl in SEE countries;

- Examining the correlation between $\mathrm{GCl}$ and $\mathrm{KEI}$ in SEE countries;

- Analysis of influence of pillar within KEI on GCl in SEE countries.

\subsection{Analysis of SEE countries' competitiveness according to $\mathrm{GCl}$ and KEI}

Analysis of SEE countries' competitiveness is based on data about rank and score of $\mathrm{GCl}$, presented by the World Economic Forum and data about rank and score of KEl, presented by the World Bank. Table 1 shows the position of SEE countries according to rank and score of $\mathrm{GCl}$ for 2012, as well as the average score.

Table 1 - Rank i score of GCl for SEE countries (2012)

\begin{tabular}{|l|c|c|}
\hline \multirow{2}{*}{ Countries } & \multicolumn{2}{c|}{$\mathrm{GCl} 2012$} \\
\cline { 2 - 3 } & Score & Rank \\
\hline Albania & 3.9 & 89 \\
\hline$B \& H$ & 3.9 & 88 \\
\hline Bulgaria & 4.3 & 62 \\
\hline Croatia & 4 & 76 \\
\hline Greece & 3.9 & 96 \\
\hline Macedonia, FYR & 4 & 79 \\
\hline Moldova & 3.9 & 87 \\
\hline Romania & 4.1 & 78 \\
\hline Serbia & 3.9 & 95 \\
\hline Turkey & 4.5 & 43 \\
\hline Average & 4.04 & - \\
\hline
\end{tabular}

Source: The Word Economic Forum (WEF): The Global Competitiveness Reports 2012 - 2013, http://www3.weforum.org/docs/WEF_GlobalCompetitivenessReport_2012-13.pdf

Based on table 1 it can be concluded that Turkey has the largest score of $\mathrm{GCl}(4.5)$, followed by Bulgaria (4.3), and Romania (4.1). Other countries record a uniform values. Recorded score of $\mathrm{GCl}$ in Croatia and Macedonia is 4, while the lowest score of $\mathrm{GCl}$ (3.9) is recorded in five countries (Albania, B\&H, Greece, Moldova and Serbia). The differences are more drastic if we observe ranks of SEE countries on the world list of countries. The best positioned SEE country is Turkey on the $43^{\text {rd }}$ place out of the 144 countries analyzed by the WEF in 2012. The worst positioned SEE country in 
Krstić B. et al.: The Influence of Knowledge Economy Development on...

the world rankings by $\mathrm{GCl}$ is $\mathrm{Greece}$, on the $96^{\text {th }}$ place, and immediately after, Serbia, on the $95^{\text {th }}$ place.

Countries in which are recorded lower scores than the average $\mathrm{GCl}$ score for SEE countries as a whole are: Albania, B\&H, Croatia, Greece, Macedonia, Moldova, Romania and Serbia. Only Bulgaria and Turkey record higher score of $\mathrm{GCl}$ than the average score for the analyzed group of countries.

In recognition of the fact that the WEF ranked total 144 countries in 2012, it can be conclude that, in addition of Bulgaria and Turkey, all SEE countries are located in the other half of the world list according to $\mathrm{GCl}$.

Table 2 shows the position of the SEE countries according to rank and score of KEI. The World Bank analyzed and ranked total 145 countries in 2012.

Table 2 - Rank and score of KEI for SEE countries (2012)

\begin{tabular}{|l|c|c|}
\hline \multirow{2}{*}{ Countries } & \multicolumn{2}{|c|}{2012} \\
\cline { 2 - 3 } & Score & Rank \\
\hline Albania & 4.53 & 82 \\
\hline B\&H & 5.12 & 70 \\
\hline Bulgaria & 6.80 & 45 \\
\hline Croatia & 7.29 & 39 \\
\hline Greece & 7.51 & 36 \\
\hline Macedonia, FYR & 5.65 & 57 \\
\hline Moldova & 4.92 & 77 \\
\hline Romania & 6.82 & 44 \\
\hline Serbia & 6.02 & 49 \\
\hline Turkey & 5.16 & 69 \\
\hline Average & 5.98 & - \\
\hline
\end{tabular}

Source: The World Bank (WB), Knowledge Economy Index (KEI) 2012 Rankings, http://siteresources.worldbank.org/INTUNIKAM/Resources/2012.pdf

Greece records the highest score of KEl among SEE countries (7.51), immediately followed by Croatia (7.29). Countries with the lowest score of KEI are Moldova (4.92) and Albania (4.53). The best-placed SEE country in the world rankings, Greece, is located at $36^{\text {th }}$ position out of 145 analyzed countries, while the weakest positioned Albania lags behind Greece by 46 positions, situated on $82^{\text {nd }}$ place.

Countries, which record a lower value of $\mathrm{KEI}$ compared to the average value of the SEE countries, are: Albania, B\&H, Macedonia, Moldova, and Turkey.

Considering 145 countries analyzed by the World Bank, it can be concluded that, the exception of Albania, all SEE countries are located in the first half of the world list according to KEl. 
Krstić B. et al.: The Influence of Knowledge Economy Development on...

Table 3 presents the results of descriptive statistics according to score of $\mathrm{GCl}$ and $\mathrm{KEI}$ in SEE countries in 2012.

Table 3 - Results of descriptive statistics for SEE countries according to score of GCI and KEl in 2012

\begin{tabular}{|c|c|c|c|c|c|c|}
\hline Indicators & $\mathrm{N}$ & Minimum & Maximum & Mean & $\begin{array}{c}\text { Std. Devia- } \\
\text { tion }\end{array}$ & $\begin{array}{c}\text { Variation } \\
\text { Coefficient }\end{array}$ \\
\hline $\mathrm{GCl}$ & 10 & 3.90 & 4.50 & 4.0400 & 0.20656 & 5.113 \\
\hline $\mathrm{KEl}$ & 10 & 4.53 & 7.51 & 5.9820 & 1.06372 & 17.782 \\
\hline
\end{tabular}

Minimum score of $\mathrm{GCl}$ in SEE countries is 3.90 , maximum 4.50, while the mean score is 4.04 . Minimum score of $\mathrm{KEI}$ is 4.53 , maximum 7.51 , and mean score is 5.982. Higher standard deviation is observed among $\mathrm{KEI}$ compared to the $\mathrm{GCl}$, which means that there is greater variability and heterogeneity of the analyzed countries in terms of the knowledge economy development in relation to the variability and heterogeneity of countries in terms of competitiveness. This is confirmed also by calculation of the variation coefficient for $\mathrm{KEl}$ and $\mathrm{GCl}$ (Table 3).

\subsection{Analysis of the pillar within KEl in SEE countries}

In order to assess the achievements of SEE countries in each pillar of the knowledge economy, the scores of pillar within KEI for 2012 are presented in Table 4. In order to understand the relative positions of countries according to each pillar, their average value is given in the following table.

Table 4 - Score of pillars within KEI for SEE countries in 2012

\begin{tabular}{|c|c|c|c|c|c|c|c|c|}
\hline \multirow[t]{2}{*}{ Countries } & \multicolumn{2}{|c|}{$\begin{array}{l}\text { Economic Incentive and } \\
\text { Institutional Regime }\end{array}$} & \multicolumn{2}{|c|}{ Innovation } & \multicolumn{2}{|c|}{ Education } & \multicolumn{2}{|c|}{$\mathrm{ICT}$} \\
\hline & Score* & Rank $^{* *}$ & Score* & Rank $^{* *}$ & Score* & Rank** $^{* *}$ & Score* & Rank** \\
\hline Albania & 4.69 & 8 & 3.37 & 10 & 4.81 & 9 & 5.26 & 8 \\
\hline $\mathrm{B} \& \mathrm{H}$ & 5.55 & 7 & 4.38 & 8 & 5.77 & 7 & 4.77 & 9 \\
\hline Bulgaria & 7.35 & 2.5 & 6.94 & 3 & 6.25 & 3 & 6.66 & 4 \\
\hline Croatia & 7.35 & 2.5 & 7.66 & 2 & 6.15 & 4 & 8 & 1 \\
\hline Greece & 6.8 & 4 & 7.83 & 1 & 8.96 & 1 & 6.43 & 5 \\
\hline Macedonia & 5.73 & 6 & 4.99 & 7 & 5.15 & 8 & 6.74 & 3 \\
\hline Moldova & 4.44 & 9 & 4.16 & 9 & 5.79 & 6 & 5.28 & 7 \\
\hline Romania & 7.39 & 1 & 6.14 & 5 & 7.55 & 2 & 6.19 & 6 \\
\hline Serbia & 4.23 & 10 & 6.47 & 4 & 5.98 & 5 & 7.39 & 2 \\
\hline Turkey & 6.19 & 5 & 5.83 & 6 & 4.11 & 10 & 4.5 & 10 \\
\hline $\begin{array}{l}\text { Average } \\
\text { score }\end{array}$ & 5.97 & - & 5.78 & - & 6.05 & - & 6.12 & - \\
\hline
\end{tabular}

Source: The World Bank (WB), http://info.worldbank.org/etools/kam2/KAM_page5.asp 
Krstić B. et al.: The Influence of Knowledge Economy Development on...

Pillar ICT records the highest average value (6.12), followed by Education (6.05), then the Economic Incentive and Institutional Regime (5.97) and Innovation (5.78). Observing countries, the countries which record the lower value of pillar Economic Incentive and Institutional Regime in relation to its average value are: Albania, B\&H, Macedonia, Moldova and Serbia. The country with the highest value of pillar Economic Incentive and Institutional Regime is Romania (7.39). Bulgaria and Croatia are slightly behind Romania (recorded value of pillar Economic Incentive and Institutional Regime is 7.35). The lowest value of this pillar is recorded in Serbia (4.23). Countries with the lower value of pillar Innovation in comparison to its average value are: Albania, B\&H, Macedonia and Moldova. The lowest value of pillar Innovation is recorded in Albania (3.37) and the highest in Greece (7.83). Countries in which the value of pillar Education is lower than its average value are: Albania, B\&H, Macedonia, Moldova, Serbia and Turkey. Minimum value of pillar Education is recorded in Turkey (4.11), and the highest in Greece (8.96). The lower value of pillar ICT than its average value is recorded in the following countries: Albania, B\&H, Moldova and Turkey. Serbia has the highest, while Turkey has the lowest value of ICT. Observing values of the pillars within $\mathrm{KEI}$, and ranks of SEE countries, the quite heterogeneity is evident. Thus, the hypothesis $\mathrm{H} 1$ is confirmed.

\subsection{Examining the correlation between $\mathrm{GCl}$ and $\mathrm{KEI}$ in SEE countries}

In order to examine the interdependence between competitiveness (measured by $\mathrm{GCl}$ ) and knowledge economy development (measured by KEI) in SEE countries, the method of correlation analysis is applied (Table 5).

Table 5 - Correlation coefficient between score of GCl and score of KEl in SEE countries (2012)

\begin{tabular}{|l|l|r|}
\hline & & $\mathrm{GCl}$ \\
\hline $\mathrm{GCl}$ & Correlation Coefficient & 1.000 \\
\hline & Sig. (2-tailed) &. \\
\hline & $\mathrm{N}$ & 10 \\
\hline $\mathrm{KEI}$ & Correlation Coefficient & 0.279 \\
\hline & Sig. (2-tailed) & 0.435 \\
\hline & $\mathrm{N}$ & 10 \\
\hline
\end{tabular}

Determined value of the correlation coefficient between $\mathrm{GCl}$ and $\mathrm{KEI}$ of 0.297 indicates a weak positive correlation. In this way, it can be concluded that the competitiveness of SEE countries is not based on knowledge, as a factor that in modern economy offers significant opportunities for competitiveness enhancement.

Table 6 shows: a) correlation between $\mathrm{GCl}$ and pillars within $\mathrm{KEI}$, as well as b) correlation between $\mathrm{KEI}$ and pillars within $\mathrm{KEI}$. 
Krstić B. et al.: The Influence of Knowledge Economy Development on...

Table 6 - Correlation coefficient between GCI and KEI with pillar within KEI in SEE countires (2012)

\begin{tabular}{|c|c|c|c|c|c|c|}
\hline Indicators & ত্ত & 亗 & 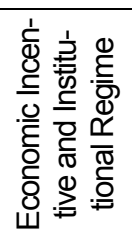 & 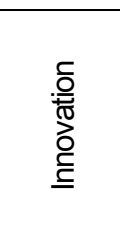 & 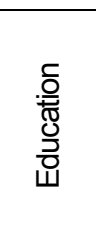 & $\underline{\underline{U}}$ \\
\hline $\mathrm{GCl}$ & 1.000 & & & & & \\
\hline KEI & 0.279 & 1.000 & & & & \\
\hline $\begin{array}{l}\text { Economic } \\
\text { Incentive and } \\
\text { Institutional } \\
\text { Regime }\end{array}$ & $0.687\left(^{*}\right)$ & $0.699\left(^{*}\right)$ & 1.000 & & & \\
\hline Innovation & 0.272 & $\left.0.9522^{* \star}\right)$ & 0.584 & 1.000 & & \\
\hline Education & -0.032 & $0.818\left(^{* \star}\right)$ & 0.535 & $0.745\left(^{*}\right)$ & 1.000 & \\
\hline ICT & -0.006 & 0.624 & 0.170 & 0.612 & 0.503 & 1.000 \\
\hline
\end{tabular}

Analysis of the correlation between $\mathrm{GCl}$ and pillars within $\mathrm{KEl}$ indicates the existence of a moderate positive correlation between $\mathrm{GCl}$ and pillar Economic Incentive and Institutional Regime (0.687). Weak positive correlation is found between $\mathrm{GCl}$ and pillar Innovation (0.272). Negative correlation is found between $\mathrm{GCl}$ and pillar Education (-0.032) and between $\mathrm{GCl}$ and pillar ICT $(-0.006)$.

Bearing in mind the above-noted and presented in tables 5 and 6 , it can be concluded that the hypothesis $\mathrm{H} 2$ is confirmed.

Testing correlation between KEl and its pillars indicates the existence of very strong direct correlation between KEI and Innovation (0.952) and strong direct correlation between KEl and Education (0.818). Moderate strong positive correlation is recorded between KEI and pillar Economic Incentive and Institutional Regime and pillar ICT, 0.699 and 0.624 respectively.

\subsection{Analysis of influence of pillars within $\mathrm{KEI}$ on $\mathrm{GCl}$ in SEE countries}

Regression analysis is used in order to examine the influence of the pillars within KEI on $\mathrm{GCl}$. Results of the analysis are presented in Table 7. 
Krstić B. et al.: The Influence of Knowledge Economy Development on...

Table 7 - The influence of pillar within KEI on GCI in SEE countries (2012)

\begin{tabular}{|l|c|c|c|c|c|}
\hline \multirow{2}{*}{} & \multicolumn{2}{|c|}{$\begin{array}{c}\text { Unstandardized } \\
\text { Coefficients }\end{array}$} & $\begin{array}{c}\text { Standardized } \\
\text { Coefficients }\end{array}$ & \multirow{2}{*}{$\mathrm{t}$} & \multirow{2}{*}{ Sig. } \\
\cline { 2 - 4 } & $\mathrm{B}$ & $\begin{array}{c}\text { Std. } \\
\text { Error }\end{array}$ & Beta & & \\
\hline (Constant) & 4.340 & 0.279 & & 15.547 & 0.000 \\
\hline $\begin{array}{l}\text { Economic Incentive and } \\
\text { Institutional Regime }\end{array}$ & 0.078 & 0.044 & 0.467 & 1.769 & 0.137 \\
\hline Innovation & 0.111 & 0.049 & 0.813 & 2.258 & 0.074 \\
\hline Education & -0.121 & 0.035 & -0.806 & -3.475 & 0.018 \\
\hline ICT & -0.110 & 0.047 & -0.609 & -2.359 & 0.065 \\
\hline
\end{tabular}

Dependent Variable: $\mathrm{GCl}$

R Square $=0.829$

The highest, but still modest influence on the GCl among analyzed four pillars in SEE countries has pillar Innovation (0.111). Positive influence has also pillar Economic Incentive and Institutional Regime (0.078). The negative value of the regression coefficient is recorded for Education and ICT. In this way, the hypothesis $\mathrm{H} 3$ is confirmed.

\section{Conclusion}

Knowledge economy is primarily based on greater efficiency and effectiveness of creating and using knowledge as a development resource. Fundaments of the knowledge economy development presented through the methodology of Knowledge Economy Index, and analyzed on a group of SEE countries discover new ideas, perspectives and requirements for managers in companies and policy makers. Creating greater value for customers, greater value for shareholders, but also a higher gross domestic product of SEE countries, should be based on the benefits of the knowledge economy. Innovative policies, greater investments in education and training, creation of innovations and technological competences, information infrastructure, as well as, stimulating economic environment and institutional regime with the aim of creating, disseminating, transferring, and effective use of knowledge in production, services, and export of SEE countries, are needed.

The analysis of competitiveness of SEE countries according to $\mathrm{GCl}$ leads to the conclusion that, out of the ten analyzed countries, eight countries are located in the second half of the world list. Only Turkey and Bulgaria are located in first half of the world list according to $\mathrm{GCl}$. The situation is better if we observe the position of the SEE countries according KEl. Specifically, all SEE countries, except Albania, are located in the first half of the world list according to KEl. Greater variability and heterogeneity among the analyzed countries is registered in terms of the knowledge economy development in relation to the variability and heterogeneity of countries in terms 
Krstić B. et al.: The Influence of Knowledge Economy Development on...

of competitiveness. When we consider pillars within $\mathrm{KEI}$, the highest average value in SEE countries is recorded for pillar ICT (6.12), followed by Education (6.05), then Economic Incentive and Institutional Regime (5.97) and Innovation (5.78). Looking at the value of pillar within $\mathrm{KEl}$, as well as ranks of the observed group of SEE countries, quite heterogeneity among these countries is also evident.

The determined value of the correlation coefficient between $\mathrm{GCl}$ and $\mathrm{KEI}$ of 0.297 indicates a weak positive correlation. In this way, it can be concluded that the competitiveness of SEE countries is not based on knowledge as a key development resource in the modern economy. The correlation analysis also shows the existence of moderate positive correlation between $\mathrm{GCl}$ and pillar Economic Incentive and Institutional Regime (0.687). A positive correlation of $\mathrm{GCl}$ was found only more with pillar Innovation (weak positive correlation -0.272 ), while negative correlation is observed with Education (-0.032) and ICT (-0.006). Using regression analysis to determine the influence of pillars within $\mathrm{KEI}$ on $\mathrm{GCl}$ shows a modest positive influence of pillars Innovation (0.111) and Economic Incentive and Institutional Regime (0.078). The negative value of the regression coefficient is recorded for Education (-0.121) and ICT (0.110).

Limitation of the research is the heterogeneity of SEE countries. The analysis shows that the SEE countries are not homogeneous in terms of $\mathrm{GCl}$, as well as in terms of $\mathrm{KEI}$. Higher degree of heterogeneity is noted in terms of $\mathrm{KEI}$.

\section{References}

Andriessen, D. (2004). Making Sense of Intellectual Capital - Designing a Method for Valuation of Intangibles. Burlington: Elsevier Butterworth-Heinemann.

Bedford, A. D. (2013). Expanding the Definition and Measurement of Knowledge Economy: Integrating Triple Bottom Line Factors into Knowledge Economy Index Models and Methodologies. Journal of Modern Accounting and Auditing, 9(2), 278-286.

Bratianu, C., \& Dinca, V. (2010). Knowledge Economy Dimensions, Review of International Comparative Management, 11(2), $210-220$.

Brinkley, I. (2006). Defining the Knowledge Economy, London: The Work Foundation.

Chen D., Dahlman C. (2005). The Knowledge Economy, the KAM Methodology and World Bank Operations. World Bank Institute Working Paper No. 37256. Retrieved from http://ssrn.com/abstract=641625 (17.04.2013)

Daniels, J., Radebaugh, L., \& Sullivan D. (2002). Globalization and Business. New Jersey: Prentice Hall.

Department of Commerce (DOC), Advisory Committee on Measuring Innovation in the 21st Century Economy. Innovation Measurement: Tracking the State of Innovation in the American Economy. Report to the Secretary of Commerce. Retrieved from http//www.esa.doc.gov/Reports/innovation-measurement-tracking-stateinnovation-america-economy (20.04.2013)

Donaldson B., \& O' Toole T. (2002). Strategic Market Relationships - From Strategy to Implementation, New York: John Wiley \& Sons, Ltd. 
Krstić B. et al.: The Influence of Knowledge Economy Development on...

Drucker, P. (1992). The Age of Discontinuity - Guidelines to Our Changing Society. New Brunswick: Transaction Publishers.

Foray, D. (2004). The Economics of Knowledge, Cambridge: MIT Press.

Javalgi, G. R., Gross, C. A., Benoy, W. J., Granot, E. (2011). Assessing competitive advantage of emerging markets in knowledge intensive business services. Journal of Business \& Industrial Marketing, 26(3), 171-180.

OECD. (1996). The Knowledge-Based Economy. Paris: OECD. Retrieved from http://www.oecd.org/science/sci-tech/1913021.pdf (01.05.2013)

OECD. (2012). New Sources of Growth, Knowledge - Based Capital Driving Investment and Productivity in the 21st Century. Paris: OECD. Retrieved from http://www.oecd.org/sti/50498841.pdf (02.04.2013)

Peters A. M. (2010). Three Forms of the Knowledge Economy: Learning, Creativity and Openness. British Journal of Educational Studies, 58(1), $67-88$.

Powell, W., \& Snellman, K. (2004). The Knowledge Economy. Annual Review of Sociology, 30, 199-220.

Teece, D. J. (2000). Managing Intellectual Capital. Oxford: Oxford University Press.

The Word Economic Forum. (2013). The Global Competitiveness Reports 2012 $2013 . \quad$ Retrieved from http://www3.weforum.org/docs/WEF GlobalCompetitivenessReport 2012-13.pdf (15.04.2013)

The World Bank. (2012). Knowledge Economy Index (KEI) 2012 Rankings. Retrieved from http://siteresources.worldbank.org/INTUNIKAM/Resources/2012.pdf (01.05.2013)

The World Bank. Retrieved from http://info.worldbank.org/etools/kam2/KAM page5.asp (31.04.2013)

Thissen R., Andriesen D., \& Deprez Lekanne F. (1999). Creating High - performance Companies trough Value - based Knowledge Management THE KNOWLEDGE DIVIDEND. London: Pearson Education Limited.

Watkins, T., \& Yandle, B. (2010). Can Freedom and Knowledge Economy Indexes Explain Go-Getter Migration Patterns? The Journal of Regional Analysis and Policy, 40(2), 104-115.

Wickham A. P. (2001). Strategic Entrepreneurship - A Decision-Making Approach to New Venture Creation and Management. London: Pearson Education Limited.

World Bank Institute. (2004). Benchmarking Countries in the knowledge economy: Presentation of the Knowledge Assessment Methodology (KAM), Knowledge for development program. Retrieved from http://siteresources.worldbank.org/KFDLP/Resources/KAMBoardBriefing.pdf (25.04.2013)

Zitek, V., \& Klimova, V. (2011, August). Knowledge economy and Knowledge Infrastructure, Paper presented at the International Conference on Applied Economics, Italy. Retrieved from http://kastoria.teikoz.gr/icoae2/wordpress/wpcontent/uploads/2011/10/084.pdf 